American Journal of Biochemistry and Biotechnology 7 (2): 55-62, 2011

ISSN 1553-3468

(C) 2011 N.F. Alhusseini et al., This open access article is distributed under a Creative Commons Attribution

(CC-BY) 3.0 license

\title{
Tolemerase Reverse Transcriptase Gene Expression as a Tumor Marker for Hepatocellular Carcinoma
}

\author{
${ }^{1}$ Amal Abou El-Fadle, ${ }^{1}$ Naglaa Fathy Al Husseini \\ ${ }^{1}$ Adel F. Al-Kholy, ${ }^{1}$ Omnia Al-Said, ${ }^{2}$ Naglaa Al-Toukhy and ${ }^{2}$ M. Magdi Atta \\ ${ }^{1}$ Department of Medical Biochemistry, \\ ${ }^{2}$ Department of Hepatology, Gastroenterology and Infectious Diseases \\ Faculty of Medicine, Benha University, Egypt
}

\begin{abstract}
Problem statement: Hepatocellular carcinoma will emerge as a major form of malignancy in the coming decades. The continuing high incidence of hepatocellular carcinoma, suggests that this disease will continue to represent a global health problem far into the future. Different genes encode for the various components of the human telomerase complex. These components include the human Telomerase RNA Component (hTERC) and the Telomerase Catalytic Subunit (hTERT). Correlation between Telomerase Reverse Transcriptase (hTERT) expression and telomerase activity has been reported in cancer patients. This work aimed to clarify the significance of human Telomerase Reverse Transcriptase (hTERT mRNA) as a potential molecular tumor marker for Hepatocellular Carcinoma (HCC). Approach: The current study included 25 patients of hepatocellular carcinoma (HCC), 30 patients with liver cirrhosis and 25 age and sex matched individuals with normal laboratory and Image findings as a control group. hTERT mRNA was measured in plasma by Real time PCR in all patients samples in comparison with normal healthy controls. Results: The expression of hTERT mRNA by relative unit was $129.10 \pm 27.6$ with range (67.72-69.6) Vs

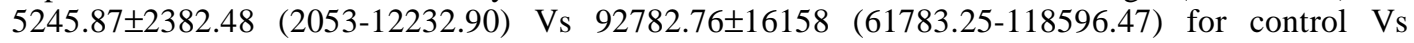
cirrhosis Vs HCC group respectively. The hTERT expression was significantly with 699 and 33 fold increase in HCC and cirrhosis groups correspondingly when compared to that of controls $\mathrm{p}<0.05$. Conclusion: It was suggested that this procedure was highly discriminating between healthy subjects and cancer patients and strongly support the idea that a valuable diagnostic test for cancer might be developed using this genetic marker in plasma. However it needs to be combined with other markers in future studies to be more specific for liver cancer.
\end{abstract}

Key words: Hepatocellular carcinoma, Telomerase Catalytic Subunit (hTERT), telomerase reverse, real time PCR, tumor marker, gene expression, diagnostic test, global health problem, cancer patients, DNA-protein structures

\section{INTRODUCTION}

Hepatocellular Carcinoma (HCC) represents the fifth most common form of neoplastic diseases worldwide (accounting for $>5 \%$ of all human cancers) and the third most common cause of cancer-related death. It is also the ninth cause of cancer deaths in the united states (Altekruse et al., 2009) and one of the fastest rising tumors as a result of chronic hepatitis $\mathrm{B}$ and C infection (Gupta and Misra, 2010). The world regions of highest incidence of hepatocellular carcinoma include Eastern Asia and Sub-Saharan Africa (Gupta and Misra, 2010). Hepatocellular carcinoma will emerge as a major form of malignant cancer in the coming decades. The continuing high incidence of hepatocellular carcinoma, suggests that this disease will continue to represent a global health problem far into the future (Bruix and Sherman, 2011). Considerable effort has been expended toward identification of noninvasive detection of hepatocellular carcinoma. The ideal biomarker for this type of application is one that can be detected with good sensitivity in a biological sample from the patient in a noninvasive manner. For hepatocellular carcinoma, blood represents the best source for detection of cancerrelated biomarkers (Bruix and Sherman, 2011). Telomeres are specialized DNA-protein structures that cap the ends of linear chromosomes (Caterina et al., 2011). The telomeric structure is crucial for protecting linear chromosomes from fusion by cellular DNA

Corresponding Author: Naglaa Fathy Alhusseini, Department of Medical Biochemistry, Faculty of Medicine, Benha University, Egypt 
repair processes and thus telomeres are essential for maintaining the integrity and stability of genomes. Dysfunctional telomeres, therefore, can lead to genomic instability, which is a common cause and hallmark of cancer and has also been proposed to contribute to aging.Telomerase is a large Ribonucleoprotein (RNP) complex that plays a major role in the maintenance of telomere DNA at the ends of linear chromosomes thus compensating for the continued erosion of telomeres with cell divisions (Caterina et al., 2011). Over $80 \%$ of human cancers show an activation of telomerase which stabilizes telomeres thus facilitating immortal proliferation of cells and making it a promising target for cancer therapy (Xianling et al., 2008). In human cancer the activation of telomerase often correlates with tumor progression. Telomerase is significantly activated in HCC and that in chronic liver diseases such as Liver Cirrhosis (LC) and Chronic Hepatitis ( $\mathrm{CH})$ but it is significantly lower than that in HCC because human Telomerase Reverse Transcriptase (hTERT) mRNA is up-regulated in the multistep process of hepatocarcinogenesis (Braicu et al., 2009). So the present study aimed to clarify the significance of human telomerase reverse transcriptase (hTERT mRNA) catalytic subunit as a tumor marker for detection of Hepatocellular Carcinoma (HCC).

\section{MATERIALS AND METHODS}

From patients who attending the Hepatology, Gastroenterology and Infectious Diseases, Benha University Hospital between January and August 2010, fifty five patients were consecutively recruited for participation in this study. The procedures used in this study followed the protocol approved by the local institutional review board. The research objectives were explained to each patient and consent was obtained. The selected patients categorized to HCC group: Included twenty five patients; 15 males and 10 females within the age range of 44-78 years, diagnosed to have Hepatocellular Carcinoma (HCC) depending on detection of focal hepatic lesions with typical radiological features of HCC by ultrasonography and Triphasic Contrast-enhanced Computed Tomography with or without Alpha fetoprotein level higher than 200ng $\mathrm{mL}^{-1}$. Cirrhosis group: Included thirty patients with liver cirrhosis; 17 males and 13 females within age range of 50-74 years and free of diagnostic criteria of HCC. All patients were classified to child A, B or C classes according to Child-Pugh classification (Pugh et al., 1973). Twenty five healthy volunteers 16 males and 9 females, within age range of 42-66 years and proved to be negative to $\mathrm{HCV} \mathrm{Ab}, \mathrm{HBsAg}$ were selected as control group (Fig. 1 and 2).
Sample collection: Five $\mathrm{ml}$ of anti-cubital venous blood were collected from each case and immediately put in a vaccutainer tube containing EDTA and centrifuged at $3500 \mathrm{rpm}$ to separate plasma and then stored at $-80^{\circ} \mathrm{C}$ for further processing (Table 1 and 2).

Total RNA extraction: Total RNA was extracted using Gene JET $^{\mathrm{TM}}$ RNA Purification kit, (Fermentas) following the manufacturer instructions and the standard protocol. Fifty $\mu \mathrm{l}$ of the eluted RNA was collected immediately, placed in ice or stored at $-20^{\circ} \mathrm{C}$ for further processing.

Spectrophotometric quantification of RNA: To ensure significance, A260 readings should be greater than 0.15.An absorbance of 1 unit at $260 \mathrm{~nm}$ corresponds to $44 \mu \mathrm{g}$ of RNA per $\mathrm{mL}$. The ratio between the absorbance values at 260 and $280 \mathrm{~nm}$ gives an estimate of RNA purity (Alhusseini et al., 2010), 10 $\mu \mathrm{L}$ of each RNA sample was diluted to $500 \mu \mathrm{l}$ by D.W $\mathrm{PH}=7.0$ (1:50 dilution).Measurement of the absorbance of the diluted sample in a $1 \mathrm{ml}$ cuvette (RNase free) at A260 and A280.Concentration of RNA sample was measured: $=44 \mu \mathrm{g} \mathrm{m} \mathrm{L} \mathrm{m}^{-1} \times \mathrm{A} 260 \times$ dilution factor. $\mathrm{A} 260$ and A280 were taken by UV spectrophotometer (Optima SP-3000+, Japan). The ratio of the readings at 260 and 280nm (A260/A280) provides an estimate of the purity of RNA. Pure RNA has an A260/A280 ratio of 1.9-2.3

Relative Quantitation of $m$ RNA of the respective genes by real time PCR using SYBR green: The target gene sequences was the catalytic subunit of hTERT and the calibrator sample is healthy control. The reference gene (housekeeping gene) was GAPDH. RQ provides accurate comparison between the initial levels of template in each sample, without requiring the exact copy number of the template. Also the relative levels of samples can be determined without the use of standard curves. A singleplex reaction have been used in this study, we did one-step RT-PCR using QuantiTect ${ }^{\circledR}$ SYBR $^{\circledR}$ Green RT-PCR master mix kit (Qiagen. GmbH). In ABI 7900 (Applied Biosystem.) the real time machine the prepared reaction components were done in 96 well PCR plate using real time cycler conditions of $48^{\circ} \mathrm{C}$ for $30 \mathrm{~min}$, (Reverse transcription), $95^{\circ} \mathrm{C}, 15 \mathrm{~min}$, (Initial denaturation) followed by 40 cycles of $94^{\circ} \mathrm{C}, 30 \mathrm{sec}$, $48^{\circ} \mathrm{C}, 1 \mathrm{~min}$ and $72^{\circ} \mathrm{C}, 1 \mathrm{~min}$ for Denaturation, Annealing, Extension steps respectively. Primer sequence of hTERT was 5'- CTT TTA TGT CAC GGA GAC CAC -3' (5'-3' sequence forward) and 5'TAA TAC GAC TCA CTA TAT AGT CCA TGT TCA CAA TCG G-3' (5'-3' sequence reverse). 
Am. J. Biochem. \& Biotech., 7 (2): 55-62, 2011

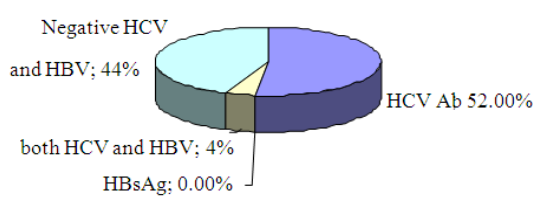

$\square$ HCV Ab $\square$ HBsAg $\square$ Both HCV and HBV $\square$ Negative HCV and HBV

Fig. 1: Percentage of viral hepatitis infection in HCC patients

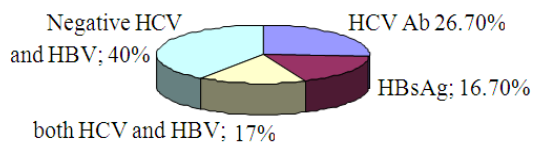

$\square$ HCV Ab $\square$ HBsAg $\square$ Both HCV and HBV $\square$ Negative HCV and HBV

Fig. 2: Percentage of viral hepatitis infection amonge cirrhotic patients

Primer sequence of glyceraldehyde phosphate dehydrogenase (GAPDH) as internal control (housekeeping gene) was 5' -TGA TGA CAT CAA GAA GGT GGT GAA G-3' (5'-3' sequence forward) and 5'-TCC TTG GAG GCC ATG TGG GCC AT-3' (5'-3' sequence reverse). The PCR primers were synthesized by (Operon, inc. Huntsville, Alabama Germany).

Data analysis: According to the RQ manager program ABI SDS software (ABI 7900), the data are produced as sigmoid shaped amplification plots in which the number of cycle is plotted against fluorescence (when using linear scale). The Threshold Cycle (CT) serves as a tool for calculation of the starting template amount in each sample (Fig. 5). Because the samples of control group and also samples of cirrhosis group are used as calibrators, the expression levels are set to 1. But because the gene expression levels were plotted as $\log 10$ values $(\log 10$ of 1 is 0$)$, the expression level of the calibrator samples appear as 0 in the graph. (Alhusseini et al., 2010). Because the relative quantities of the hTERT gene are normalized against the relative quantities of the endogenous control (GAPDH) gene fold expression changes are calculated using the equation $2^{-\Delta \Delta c t}$ (Livak and Schmittgen, 2001).

Statistical analyses: The results were presented as means $\pm \mathrm{SD}$, Comparisons of categorical variables were made between cases and controls using chi-squared exact test. The Spearman's correlation coefficient was used to measure the closeness of a linear relationship between relative gene expression values. All analysis was performed using the statistics package St. Social Sciences (SPSS) and Microsoft office Excel is used for data processing and data analysis. Differences are considered as statistically significant for a $\mathrm{p}$ value less than 0.05 .

\section{RESULTS}

The expression of hTERT mRNA by relative unit was 129.10 \pm 27.6 with range (67.72-69.6) Vs $5245.87 \pm 2382.48(2053-12232.90)$ Vs $92782.76 \pm 16158$ (61783.25-118596.47) for control Vs cirrhosis Vs HCC group correspondingly Fig. 7. The expression was significantly with 699 and 33 fold increase in HCC when compared to control and cirrhosis correspondingly Fig. 8 and $9 \mathrm{p}<0.05$. As regards to tumors in $\mathrm{HCC}$ patients, eighteen HCC patients have a tumor size more than $5 \mathrm{~cm}$ while 7 have it less than $5 \mathrm{~cm}$. It also shows that 13 patients have their focal lesion in the left lobe while 12 patients have their focal lesion in the right lobe. In addition 16 have a single focal lesion, 9 have multiple focal lesions and four patients have portal vein thrombosis. There is a statistically significant increase in hTERT mRNA level of HCC group as compared to both control and cirrhosis groups $(\mathrm{P} 1<0.05$ and $\mathrm{P} 2<0.05)$ correspondingly, however there is a slight increase in its level in cirrhosis patients as compared to controls but does not reach a significant level $(\mathrm{P} 3>0.05)$. This work reported that there is no significant correlation between hTERT mRNA level and any laboratory finding in cirrhosis group. But in HCC group a statistically significant positive correlation was found between hTERT mRNA level on one hand and both AFP and tumor size on the other hand Fig. 3 and 4, however, no significant correlation between it and any other laboratory variable was reported. The area under the ROC curve of AFP was 0.945 Vs 0.969 of that under the curve of hTERT (Fig. 6).

Gene expression levels of hTERT mRNA for both cirrhotic and HCC samples are indicated by green bars. This color also indicates the samples in RQ. Because control samples are used as calibrators, the expression levels are set to one. But because the expression levels were blotted as $\log 10$ values (and the $\log 10$ of 1 is 0 ), the expression level of the control samples appear as 0 in the graph Fig. 8. Because the relative quantities of the hTERT mRNA are normalized against the relative quantities of the GAPDH (endogenous control), the expression level of the endogenous control is 0 ; there are no bars for GAPDH. Because cirrhotic samples are used as calibrators, the expression levels are set to one. But because the expression levels were blotted as $\log 10$ values (and the $\log 10$ of 1 is 0 ), the expression level of the cirrhotic samples appear as 0 in the graph Fig. 9. 


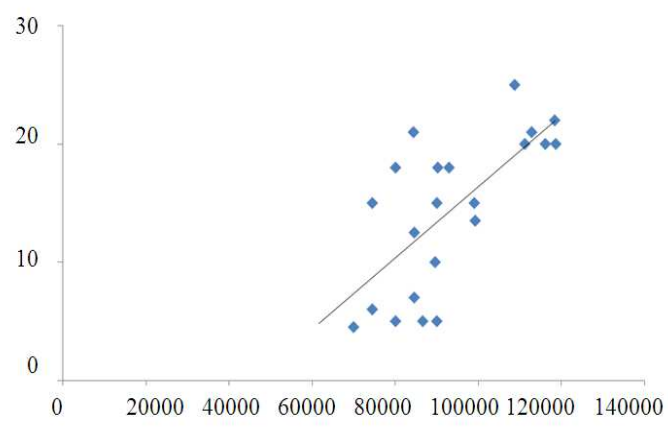

Fig. 3: Correlation between hTERT mRNA and size of tumor

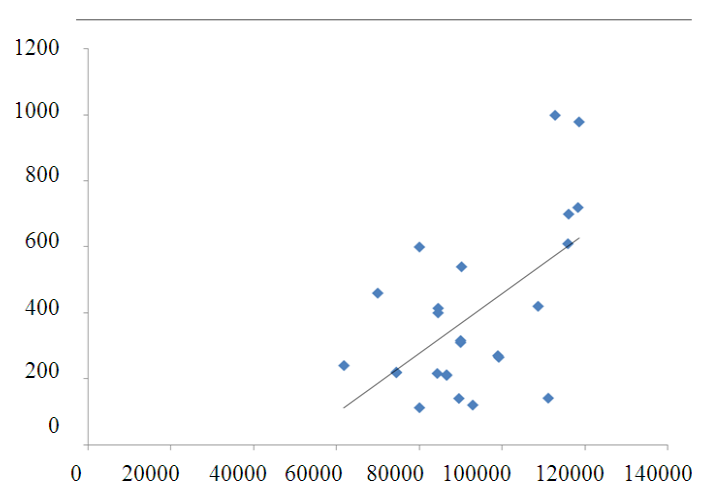

Fig. 4: Correlation between hTERT mRNA and AFP in HCC patients

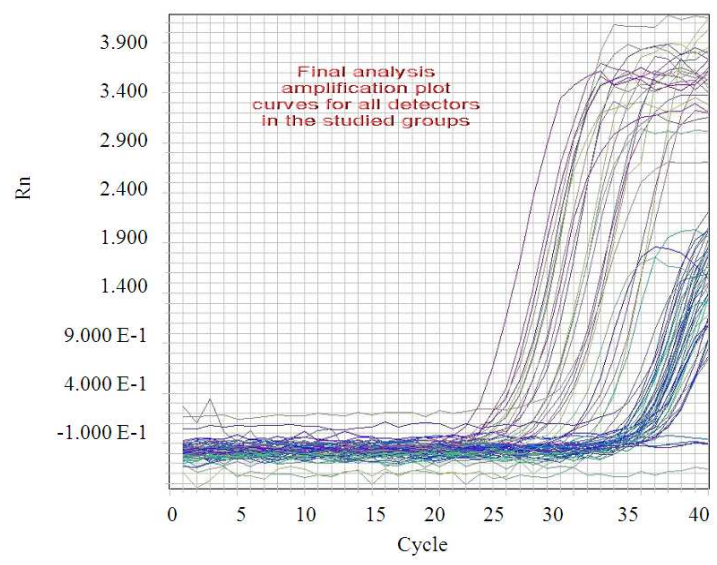

Fig. 5: Amplification plot curves for all detectors in the studied groups (Curves by ABI 7900 Real Time)

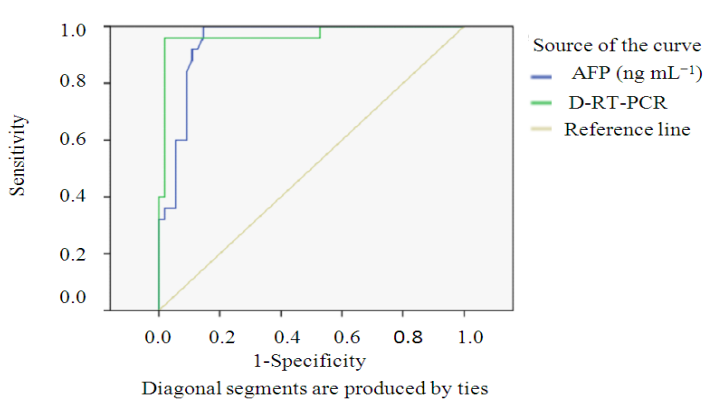

Fig. 6: ROC curve for hTERT and AFP in patients

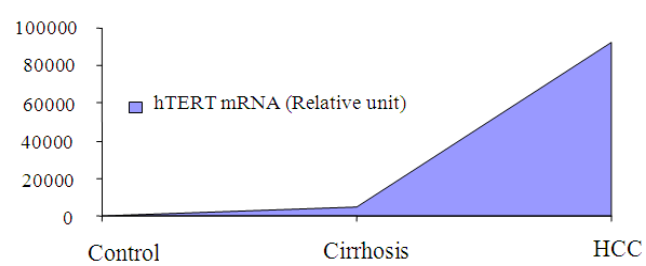

Fig. 7: hTERT mRNA (Relative unit) amonge the three studied groups

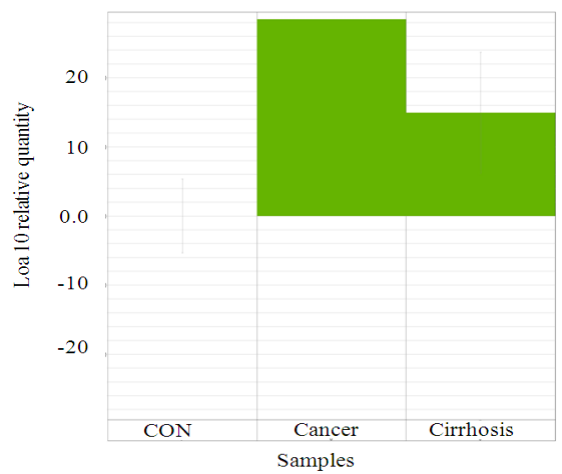

Fig. 8: Gene expression levels of hTERT mRNA for both cirrhosis and HCC relative to controls (CON: Controls)

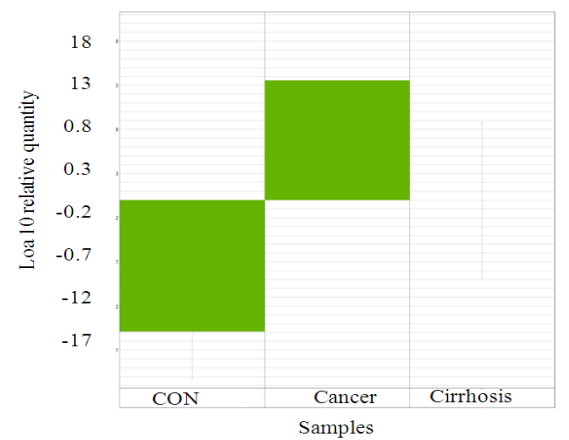

Fig. 9: Gene expression levels of hTERT mRNA for both control and HCC relative to cirrhosis 
Am. J. Biochem. \& Biotech., 7 (2): 55-62, 2011

Table 1: Clinical profile of the studied groups

\begin{tabular}{|c|c|c|c|c|c|c|c|}
\hline \multirow[b]{3}{*}{ Age (Year) } & \multicolumn{3}{|c|}{ Mean \pm SD (Range) } & \multirow[b]{2}{*}{ F } & \multirow[b]{2}{*}{$\mathrm{P}$} & \multirow{2}{*}{\multicolumn{2}{|c|}{$\mathrm{p}$ between groups }} \\
\hline & $\begin{array}{l}\text { Control } \\
\mathrm{n} .=25\end{array}$ & $\begin{array}{l}\text { Cirrhosis } \\
\mathrm{n} .=30\end{array}$ & $\begin{array}{l}\mathrm{HCC} \\
\mathrm{n} .=25\end{array}$ & & & & \\
\hline & $\begin{array}{l}53.92 \pm 6.708 \\
(42-66)\end{array}$ & $\begin{array}{l}61.87 \pm 7.491 \\
(48-74)\end{array}$ & $\begin{array}{l}63.04 \pm 7.486 \\
(44-78)\end{array}$ & 11.9 & $<0.05$ & $\begin{array}{l}* \mathrm{p} 1<0.05 \\
* \mathrm{p} 3<0.05\end{array}$ & $\mathrm{p} 2>0.05$ \\
\hline $\mathrm{HB} \quad\left(\mathrm{gm} \mathrm{dL}^{-1}\right)$ & $\begin{array}{l}13.58 \pm 1.35 \\
(11.4-16.0)\end{array}$ & $\begin{array}{l}10.4 \pm 1.13 \\
(8.1-11.9)\end{array}$ & $\begin{array}{l}10.8 \pm 1.29 \\
(8.2-13.0)\end{array}$ & 49.6 & $<0.001$ & $\begin{array}{l}* \mathrm{p} 1<0.05 \\
* \mathrm{p} 3<0.05\end{array}$ & $\mathrm{p} 2>0.05$ \\
\hline RBCs $\quad\left(\times 106 \mathrm{uL}^{-1}\right)$ & $\begin{array}{l}4.76 \pm 0.527 \\
(4-6)\end{array}$ & $\begin{array}{l}4.11 \pm 0.591 \\
(3-5)\end{array}$ & $\begin{array}{l}3.47 \pm 0.30 \\
(3-4)\end{array}$ & 47.7 & $<0.001$ & $\begin{array}{l}* \mathrm{p} 1<0.05 \\
* \mathrm{p} 3<0.05\end{array}$ & $\mathrm{p} 2>0.05$ \\
\hline WBCS $\quad\left(\times 103 \mathrm{uL}^{-1}\right)$ & $\begin{array}{l}8.36 \pm 1.770 \\
(5.5-11.2)\end{array}$ & $\begin{array}{l}7.56 \pm 2.33 \\
(4.0-10.6)\end{array}$ & $\begin{array}{l}6.56 \pm 3.87 \\
(3.8-23.8)\end{array}$ & 2.6 & $>0.05$ & $\begin{array}{l}* \text { p } 1<0.05 \\
\text { p3 }>0.05\end{array}$ & $\mathrm{p} 2>0.05$ \\
\hline Platelets $\left(\times 103 \mathrm{uL}^{-1}\right)$ & $\begin{array}{l}262.96 \pm 71.91 \\
(170-406)\end{array}$ & $\begin{array}{l}181.40 \pm 82.70 \\
(92-310)\end{array}$ & $\begin{array}{l}131.53 \pm 14.86 \\
(106-176)\end{array}$ & 40.8 & $<0.001$ & $\begin{array}{l}* \text { p } 1<0.05 \\
* \text { p3 }<0.05\end{array}$ & $\mathrm{p} 2>0.05$ \\
\hline $\begin{array}{l}\text { Liver and kidney functions } \\
\text { ALT(U/L) }\end{array}$ & $\begin{array}{l}32.03 \pm 7.85 \\
(20-46)\end{array}$ & $\begin{array}{l}33 \pm 9.99 \\
(13-44)\end{array}$ & $\begin{array}{l}76.0 \pm 46.11 \\
(20-152)\end{array}$ & 22.6 & $<0.001$ & $\begin{array}{l}* \text { p } 1<0.05 \\
\text { p3 }>0.05\end{array}$ & $* \mathrm{p} 2<0.05$ \\
\hline s.Billirubin( $\mathrm{mg} \mathrm{dL}^{-1}$ ) & $\begin{array}{l}0.424 \pm 0.198 \\
(0.1-0.8)\end{array}$ & $\begin{array}{l}5.24 \pm 3.23 \\
(1.3-15.0)\end{array}$ & $\begin{array}{l}6.56 \pm 2.125 \\
(2.6-9.6)\end{array}$ & 49.2 & $<0.001$ & $\begin{array}{l}* \mathrm{p} 1<0.05 \\
* \mathrm{p} 3<0.05\end{array}$ & $* \mathrm{p} 2<0.05$ \\
\hline s.albumin $\left(\mathrm{gm} \mathrm{dL}^{-1}\right)$ & $\begin{array}{l}4.27 \pm 0.53 \\
(3.5-5.3)\end{array}$ & $\begin{array}{l}1.82 \pm 0.58 \\
(0.8-2.9)\end{array}$ & $\begin{array}{l}1.56 \pm 0.54 \\
(0.9-2.1)\end{array}$ & 54.9 & $<0.001$ & $\begin{array}{l}* \mathrm{P} 1<0.05 \\
\mathrm{P} 2>0.05 \\
* \mathrm{P} 3<0.05\end{array}$ & \\
\hline s.creatinine $\left(\mathrm{mg} \mathrm{dL}^{-1}\right)$ & $\begin{array}{l}1.03 \pm 0.23 \\
(0.6-1.4)\end{array}$ & $\begin{array}{l}1.140 \pm 0.36 \\
(0.6-2.0)\end{array}$ & $\begin{array}{l}1.30 \pm 0.27 \\
(1.0-2.4)\end{array}$ & 4.9 & $<0.05$ & $\begin{array}{l}* \mathrm{P} 1<0.05 \\
\mathrm{P} 2>0.05 \\
\mathrm{P} 3>0.05\end{array}$ & \\
\hline $\begin{array}{l}\text { P.T } \\
\text { (seconds) } \\
\text { AFP }\left(n g \mathrm{~mL}^{-1}\right)\end{array}$ & & $\begin{array}{l}20.40 \pm 3.820 \\
(14-27) \\
62.9 \pm 63.7 \\
(24.8-125.2) \\
\end{array}$ & $\begin{array}{l}19.22 \pm 4.586 \\
(12-25) \\
325.8 \pm 244.5 \\
(112-1000)\end{array}$ & $\begin{array}{l}\text { t-test } \\
1.1\end{array}$ & $\begin{array}{c}p \\
>0.05\end{array}$ & & \\
\hline
\end{tabular}

Table 2: Percentage of the clinical picture parameters among the studied groups

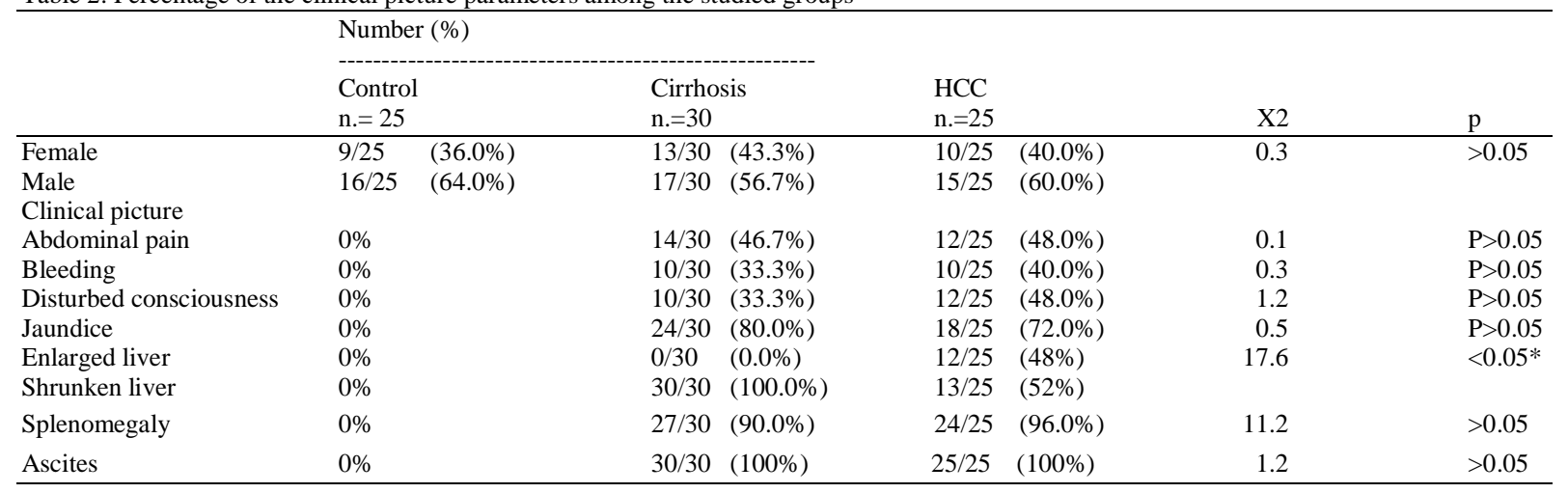

\section{DISCUSSION}

In the present study, the mRNA of the catalytic subunit of the telomerase enzyme (hTERT mRNA) was used as a target sequence for quantification, (Miura et al., 2006; Sirera et al., 2007) also used the same target. Sozzi et al. (2003) used hTERT gene itself as a target sequence for quantification of circulating DNA. Peter et al. (2010) found that quantification of mRNA of the catalytic subunit of the enzyme (TERT) was found to be superior to quantification of the whole gene encoding both TERT and telomerase RNA component (TERC) because the regulatory units controlling TERC expression and its up regulation in tumor cells are much less defined. The expression of hTERT mRNA in plasma was measured by quantitative Real time PCR (RT-PCR).

Some previous studies (Dasi et al., 2006 and Sirera et al., 2007) reported using plasma samples while some studies reported using serum samples (Miura et al., 2006).Other studies used peripheral blood lymphocytes (Jang et al., 2008). In the current work, no significant sex difference was discovered when comparing the $\mathrm{HCC}$, cirrhosis and control groups. As regards to age there was 
no statistically significant difference between cirrhosis andHCC groups. However there was a statistically significant increase in age of both HCC andcirrhosis groups as compared to control groups correspondingly. This age difference is in agreement with (Elizabeth et al., 2008) who reported an incidence of $64.9 \%$ of HCC cases in Egypt between the age of 50 and 69 years which may be explained by that liver cancer are generally attributed to $\mathrm{HCV}$ and chronic HCV most probably lead to carcinogenesis after 10-30 years following infection or may be due to late diagnosis in Egypt (Shariff et al., 2011). The higher increase of hTERT mRNA level in HCC patients were in agreement with (Braicu et al., 2009; Roessler et al., 2007; Miura et al., 2010). Although telomerase per se is not carcinogenic, it plays a direct role in oncogenesis by allowing the precancerous cells to proliferate continuously and become immortal, which can be explained by the positive correlation between telomerase activity and tumors of different histological origins and types (Cortez-Gonzalez and Zanetti, 2007). Over $80 \%$ of human cancers show an activation of telomerase which stabilizes telomeres thus facilitating immortal proliferation of cells. The activation of telomerase is a general phenomenon in different types of human cancer. In human cancer the activation of telomerase often correlates with tumor progression. Premalignant tumors show no or very little telomerase activity (Xianling et al., 2008). On the other hand, there was a slight increase in expression of hTERT mRNA level in cirrhosis patients as compared to controls but does not reach a significant level, a finding that coincides with the results reported by Miura et al. (2010) who attributed this to the fact that normal hepatocytes may express a negligible amount of hTERT-mRNA and that inflamed hepatocytes may still express more weakly than HCC cells. Shimojima et al. (2004) reported a sensitivity of $100 \%$, but their study measured hTERT-mRNA in HCC tissue and not in the peripheral blood, which might indicate that the locally expressed hTERT-mRNA may be a more sensitive predictor of HCC in tissue than in peripheral blood, but still blood samples are much more easily obtained for monitoring HCC vulnerable patients than tissue biopsies. Our results were contradictory to multiple studies that failed to explain low hTERTmRNA in some HCC cases, Cavin et al. (2003) reported that some HCC cases had low hTERT-mRNA, because of cirrhosis which may be the underlying cause for HCC, causes a high level of TGF- $\beta$, which promotes apoptosis of immortalized hepatocytes. Nittis et al. (2008) suggested that immortal hepatocytes may acquire an "Alternative Lengthening of Telomerase" (ALT) mechanism for maintenance of their chromosomal stability. We can give an explanation about these reports by previous studies that their samples were HCC tissues and the low telomerase enzymatic activity in tissue samples taken from necrotic malignant tissue possibly due to variability in the collected sample and the used technique. In the current work, no significant correlation was reported between $\mathrm{CBC}$ results, liver enzymes, serum albumin, serum creatinine or prothrombin time and hTERT mRNA expression in neither HCC or cirrhosis groups. Also, Kim et al. (2006) found no significant correlation between hTERT mRNA and any of the clinicopathological variables in cirrhosis and HCC patients. For the HCC group, the hTERT-mRNA expression levels were positively correlated with AFP and tumor size but not with site or number of the focal lesion. These findings are in agreement with (Miura et al., 2007; Braicu et al., 2009; Miura et al., 2010).However, Stravitz et al.(2008) reported that the enzyme level was significantly associated with tumor size but not AFP level.

Our findings revealed that hTERT-mRNA is a better marker than AFP as Wu et al. (2005) suggest that AFP sensitivity is lower in certain races (e.g., African Americans) and Cortez-Gonzalez and Zanetti (2007) found that AFP is significantly decreased in cirrhotic patients receiving interferon therapy for $\mathrm{HCV}$. (Farinati et al., 2006) reported that the usefulness of AFP testing for $\mathrm{HCC}$ diagnosis is seriously questioned because AFP monitoring misses many $\mathrm{HCC}$ cases and inappropriately arouses suspicion of malignancy in many cirrhotic patients. So, it has limited utility in differentiating HCC from benign hepatic disorders for its high false positive and false negative rates and also patients with acute viral exacerbation but not HCC may have remarkably elevated AFP levels. Therefore new biomarkers with better sensitivity and specificity than AFP to complement the imaging diagnosis are needed (Stravitz et al., 2008). So quantitative analysis of plasma hTERT mRNA expression was superior to AFP for the purpose of the early detection of HCC, because hTERT mRNA was detectable in HCC patients with normal AFP levels.

\section{CONCLUSION}

HTERT mRNA expression in hepatocellular carcinoma patients showed significant elevation in comparison to healthy controls and also cirrhotic patients. So, it might be a diagnostic tumor marker for HCC.A valuable diagnostic test for HCC might be developed using this genetic marker in plasma in combination with other tumor markers. hTERT mRNA 
was found to be superior to AFP as a tumor marker for HCC. hTERT mRNA level was significantly correlated with size of the focal lesions among HCC cases. So, it could be a prognostic tool for morbidity in these patients.

\section{REFERANCES}

Al Husseini, N.F., M.M. Odaa, M.A. Mohamed, W.B. Abd El Wahab and A.A. Hasan, 2010. Expression of adiponectin receptors in human placenta and its possible implication in gestational diabetes. Am. J. Biochem. Biotechnol., 6: 136-140. DOI: 10.3844/ajbbsp.2010.136.140

Altekruse, S.F., K.A. McGlynn and M.E. Reichman, 2009. Hepatocellular carcinoma incidence, mortality and survival trends in the United States from 1975-2005. J. Clin. Oncol., 27: 1485-1491. PMID: 19224838

Braicu, C., C. Burz, I. Berindan-Neagoe, O. Balacescu and F. Graur, 2009. Hepatocellular carcinoma. Tumorigenesis prediction markers. Gastroenterol., Res., 2: 191-199. DOI: 10.4021/gr2009.07.1304

Bruix, J. and M. Sherman, 2011. Management of hepatocellular carcinoma: An Update. Hepatology, 53: 1020-1022. DOI: 10.1002/hep.24199

Caterina, M.R.R.D., J.T. Willerson and Y.J. Geng, 2011. Biologic function and clinical potential of telomerase and associated proteins in cardiovascular tissue repair and regeneration. Eur. Heart J,. 32: 1190-1196. DOI: 10.1093/eurheartj/ehq450

Cavin, L.G., R. Romieu-Mourez and G.R. Panta, 2003. Inhibition of CK2 activity by TGF-beta1 promotes IkappaB-alpha protein stabilization and apoptosis of immortalized hepatocytes. Hepatology, 38: 1540-1551. DOI: 10.1016/j.hep.2003 09.019/pdf

Cortez-Gonzalez, X. and M. Zanetti, 2007. Telomerase immunity from bench to bedside. Round. J. Transl. Med., 5: 12-12. PMID: 17324292

Dasi, F., P. Martinez-Rodes, J.A. March, J. Santmaria and J.M. Martinez-Javaloyas, 2006. Real-Time Quantification of Human Telomerase Reverse Transcriptase mRNA in the Plasma of Patients with Prostate Cancer. Annals New York Acad. Sci., 1075: 204-210. DOI: 10.1196/annals.1368.028

Elizabeth, M.L., S.S. Amr, K. Ismail, A. Hablas and A.S. Ibrahim, 2008. Patterns of hepatocellular carcinoma incidence in Egypt from a populationbased cancer registry. Hepatology Res., 38: 465473. DOI: 10.1111/j.1872-034X.2007.00299.x

Farinati, F., D. Marino and M. De Giorgio, 2006. Diagnostic and prognostic role of alpha-fetoprotein in hepatocellular carcinoma: Both or neither? Am. J. Gastroenterol, 101: 524-532.

Gupta, A.K. and N. Misra, 2010. Hepatoprotective activity of aqueous ethanolic extract of chamomile capitula in paracetamol intoxicated albino rats. Am. J. Pharmacol. Toxicol., 1: 17-20. DOI: 10.3844/ajptsp.2006.17.20

Jang, J.S., Y.Y. Choi, W.K. Lee, J.E. Choi and S.I. Cha, et al., 2008. Telomere length and the risk of lung cancer. Cancer Sci., 99: 1385-1389. DOI: $10.1111 / \mathrm{j} .1349-7006.2008 .00831 . \mathrm{x}$

Kim, K.A., J.S. Lee and E.S. Jung et al., 2006. Usefulness of serum Alpha-Fetoprotein (AFP) as a marker for Hepatocellular Carcinoma (HCC) in hepatitis $\mathrm{C}$ virus related cirrhosis: Analysis of the factors influencing AFP elevation without HCC development. Korean J. Gastroenterol, 48: 321326. PMID: 17132920

Livak, K.J. and T.D. Schmittgen, 2001. Analysis of relative gene expression data using real time quantitative PCR and the 2-delta delta CT Method. PMID: 11846609

Miura, N., H. Nakamura, R. Sato, T. Tsukamoto and T. Harada et al., 2006. Clinical usefulness of serum telomerase Reverse Transcriptase (hTERT) mRNA and Epidermal Growth Factor Receptor (EGFR) mRNA as a novel tumor marker for lung cancer. Cancer Sci., 97: 1366-1373. DOI: 10.1111/j.13497006.2006.00342.x

Miura, N., Y. Osaki, M. Nagashima, M. Kohno and K. Yorozu et al., 2010. A novel biomarker TERTmRNA is applicable for early detection of hepatoma. BMC Gastroenterol, 10: 46-46 DOI: 10.1186/1471-230X-10-46

Miura, N., S. Maruyama and K. Oyama, 2007. Development of a novel assay to quantify serum human telomerase reverse transcriptase messenger RNA and its significance as a tumor marker for hepatocellular carcinoma. Oncology, 72 Suppl., 1: 45-51. PMID: 18087181

Nittis, T., L. Guittat and S.A. Stewart, 2008. Alternative Lengthening of Telomeres (ALT) and chromatin: Is there a connection? Biochem, 90: 5-12. PMID: 15950388

Peter, W., W. Johann, M. Anita, W. Siegfried and O. Friedrich et al., 2010. Telomere length and risk of incident cancer and cancer mortality. JAMA 304: 69-75. DOI: 10.1001/jama.2010.897. PMID: 20606151 
Pugh, R.N.H., I.M. Murray-Lyon and Dawson, 1973. Transaction of the oesophagus for bleeding oesophageal varices. Br. J. Surg., 60: 649-659. PMID: 4541913

Shariff, M.I.F., A.I. Gomaa, I.J. Cox, M. Patel and H.R.T. Williams et al., 2011. Urinary metabolic biomarkers of hepatocellular carcinoma in an Egyptian population. Validation Study. J. Proteome Res., 10: 1828-1836. DOI: 10.1021/pr101096f, http://physrev.physiology.org/cgi/reprint/88/2/557

Shimojima, M., F. Komine, H. Hisatomi, T. Shimizu and Moriyama et al., 2004. Detection of telomerase activity, telomerase RNA component and telomerase reverse transcriptase in human hepatocellular carcinoma. Hepatol. Res., 29: 3138. PMID: 15135344

Sirera, R.C., L. Camps, A. Liobat, R.M. Berrocal and A. Bremnes et al., 2007. The quantification of the catalytic subunit of telomerase in plasma is a prognostic factor in advanced Non-Small Cell Lung Cancer (NSCLC) patients. J. Thoracic Oncology, 2: S528. DOI: 10.1097/01.JTO.0000283557.96739.22
Sozzi, G., D. Conte, M.E. Leon, R. Ciricione and L. Roz et al., 2003. Quantification of free circulating DNA as a diagnostic marker in lung cancer. J. Clin. Oncol., 21: 3902-3908. PMID: 14507943

Stephanie, R., A. Budhu and X.W. Wang, 2007. Future of molecular profiling of human hepatocellular carcinoma. Future Oncology, 4: 429-439. DOI: 10.2217/14796694.3.4.429

Stravitz, R.T., D.M. Heuman and N. Chand, 2008. Surveillance for hepatocellular carcinoma in patients with cirrhosis improves outcome. Am. J. Med., 121: 119-126. PMID: 18261500

Wu, W., D.F. Yao and L.W. Qiu, 2005. Abnormal expression of hepatomas and circulating telomerase and its clinical values. Hepatobiliary Pancreat. Dis. Int., 4: 544-549. PMID:16286259

Xianling, G., W. Wang, F. Zhou, Z. Lu and R. Fang et al., 2008. SiRNA-mediated inhibition of hTERT enhances chemosensitivity of hepatocellular carcinoma. Cancer biology Therapy, 7: 1555-1560 PMID: 18708758 